\title{
Natural Plasmodium infection in neotropical primates in the island of Sáo Luís, state of Maranháo, Brazil
}

\author{
Infecção natural de Plasmodium em primatas neotropicais da Ilha de São Luís, \\ Estado do Maranhão, Brasil
}

Mayra Araguaia Pereira Figueiredo ${ }^{1}$; Silvia Maria Fátima Di Santi²;

Thaysa Araguaia Pereira Figueiredo; ; Rosangela Zacarias Machado ${ }^{1 *}$

\begin{abstract}
${ }^{1}$ Laboratório de Imunoparasitologia, Faculdade de Ciências Agrárias e Veterinárias - FCAV, Universidade Estadual Paulista - UNESP, Campus de Jaboticabal, Jaboticabal, SP, Brasil

${ }^{2}$ Laboratório de Malária, Superintendência de Controle de Endemias do Estado de São Paulo - SUCEN, São Paulo, SP, Brasil

${ }^{3}$ Néctar Soluçóes Sustentáveis, São Luis, MA, Brasil
\end{abstract}

Received October 8, 2014

Accepted April 22, 2015

\begin{abstract}
The states that make up the Legal Amazon Region, which include the state of Maranhão, account for 99\% of registered cases of human malaria in Brazil. It is also believed that transmission of malaria from nonhuman primates (NHP) to humans occurs in this region, because of current reports of seroepidemiological results from samples from humans and NHP coexisting in the same areas. This study aimed to make morphological, serological and molecular diagnoses of Plasmodium spp. in neotropical primates on the island of São Luís, state of Maranhão, Brazil. The diagnostic techniques used were optical microscopy, the polymerase chain reaction (PCR) and the indirect immunofluorescence assay (IFA). From June 2009 to April 2010, 70 NHP were sampled: 50 at the Wild Animal Screening Center (CETAS), located in the municipality of São Luís and 20 free-living individuals that were caught in a private reserve located in the municipality of São Jose de Ribamar, state of Maranhão. Under an optical microscope, 140 slides (two from each animal) were evaluated and five animals (7.1\%) were found to be positive. IFA did not detect anti-Plasmodium spp. From PCR on the 70 animals sampled, amplified Plasmodium spp. products were observed in 13 samples, of which eight (61.5\%) were from free-living animals and five (38.5\%) were from animals at CETAS.
\end{abstract}

Keywords: Malaria, Plasmodium spp., PCR, nonhuman primates, sylvatic cycle.

\section{Resumo}

Os Estados que compôem a Amazônia Legal, entre eles o Estado do Maranhão, respondem a 99\% dos casos registrados de malária humana no Brasil. Também se acredita que nessa região ocorra a transmissão de malária de primatas não humanos (PNH) para humanos, devido a relatos atuais de resultados soroepidemiológicos de amostras de humanos e PNH que coexistem nas mesmas áreas. O presente estudo objetivou realizar o diagnóstico morfológico, sorológico e molecular de Plasmodium spp. em primatas neotropicais na Ilha de São Luís, Estado do Maranhão, Brasil. Foram utilizadas como técnicas de diagnóstico: a microscopia de luz, a reação em cadeia pela polimerase (PCR) e a imunofluorescência indireta (RIFI). No período de junho de 2009 a abril de 2010, foram amostrados $70 \mathrm{PNH}$, sendo 50 provenientes do Centro de Triagem de Animais Silvestres (CETAS), localizado no município de São Luís, e 20 de vida livre, capturados em reserva particular localizada no município de Sáo José de Ribamar, Estado do Maranháo. Foram avaliadas pela microscopia de luz 140 lâminas (duas de cada animal), das quais cinco animais $(7,1 \%)$ foram positivos. Pela RIFI não se detectou anticorpos anti-Plasmodium spp. Pela PCR, dos 70 animais amostrados, foi possível observar produtos amplificados para Plasmodium spp. em 13 amostras, das quais oito (61,5\%) eram de animais de vida livre e cinco $(38,5 \%)$ de CETAS.

Palavras-chave: Malária, Plasmodium spp., PCR, primatas náo humanos, ciclo silvestre.

\footnotetext{
*Corresponding author: Rosangela Zacarias Machado. Laboratório de Imunoparasitologia, Departamento de Patologia Veterinária, Faculdade de Ciências Agrárias e Veterinárias - FCAV, Universidade Estadual Paulista - UNESP, Via de Acesso Paulo Donato Castellane, s/n, CEP 14884-900, Jaboticabal, SP, Brasil.

e-mail: zacarias@fcav.unesp.br
} 


\section{Introduction}

Malaria is the human parasitic disease with greatest impact on public health in tropical and subtropical areas (GUERRANT $\&$ BLACKWOOD, 1999). Brazil records around $40 \%$ of the cases of this disease in the Americas, and the states comprising the Legal Amazon Region (Acre, Amazonas, Rondônia, Roraima, Amapá, Pará, Maranhão, Mato Grosso and Tocantins) account for $99 \%$ of the cases (WHO, 2005). In the state of Maranhão, malaria still is the most important endemic disease, because of the phytogeographical aspects of the pre-Amazon region and its great proportion of rural population in relation to the urban population. Currently, this state is responsible for approximately $1 \%$ of the cases of the disease in the Legal Amazon Region (OLIVEIRA-PEREIRA \& REBÊLO, 2000)

Malaria is caused by protozoa of the genus Plasmodium, a parasite of humans and other mammals, birds and reptiles (WARREL, 2002). Approximately 200 species are known, among which 33 parasitize nonhuman primates of the Old and New Worlds (EYLES, 1963; LECLERC et al., 2004). However, in South America, only two species of Plasmodium have been described infecting NHP naturally (P. brasilianum and P. simium) and Brazil is currently the only country in which both species occur (DUARTE et al., 2006). P. simium has been diagnosed in Alouatta fusca, Alouatta guariba and Brachyteles arachnoides from areas of the Atlantic Forest biome, in southern and southeastern Brazil. P. brasilianum has a wide geographical distribution, from the Amazon Forest of Panama to Brazil and infects all genera of NHP of the subfamilies (PERELMAN et al., 2011) Cebinae and Atelinae and, rarely, specimens of Callithrichinae (COATNEY et al., 1971; DEANE, 1992). P. simium and $P$. brasilianum have genetics and morphology similar to $P$. vivax and $P$. malariae, respectively (ESCALANTE et al., 1995; ESCALANTE et al., 1998).

Due to the molecular, clinical and morphological similarities that exist between $P$. malariae and $P$. brasilianum, it is believed that in the Americas, malaria caused by $P$. malariae can have zoonotic characteristics. It is considered to be the same species that parasitizes NHP, which is called in such cases $P$. brasilianum. Thus, the name P. malariae/brasilianum can be accepted (FANDEUR et al., 2000).

Hence, the present study had the objective of morphologically, serologically and molecularly identify Plasmodium spp. in blood samples from neotropical primates at the Wild Animal Screening Center and from the Sítio Aguahy Private Reserve, located on the island of São Luís, state of Maranhão.

\section{Materials and Methods}

\section{Study areas and blood samples from nonhuman primates}

The activities were approved by the Animals Ethics Committee of FCAV-UNESP (Protocol No. 020091/09) and by the Chico Mendes Biodiversity Institute (ICMBio) (license No. 23078-1).

A total of 70 blood samples from NHP individuals belonging to the Family Cebidae (PERELMAN et al., 2011) were collected, of which 50 were from NHP at the Wild Animal Screening Center
(CETAS), which is located in the urban area of the municipality of São Luís and 20 (18 Sapajus sp. and 02 Saimiri sciureus) were from NHP caught in the Sítio Aguahy Private Reserve, which is located in the rural area of the municipality of São José de Ribamar, an area of environmental preservation named Guarapiranga, that has less than 300 inhabitants.

Both municipalities are part of the island of São Luís, state of Maranhão.

\section{Blood sampling and parasitological examination}

Blood sampling was performed through venipuncture of the jugular or femoral veins of the NHP, which had previously been anesthetized using a combination of zolazepam hydrochloride and tiletamine hydrochloride, according to each species. The samples collected were placed in Vacutainer ${ }^{\circledR}$ tubes containing EDTA and in tubes without anticoagulant (in order to separate the serum), and were transported in ice to the Immunoparasitology Laboratory of FCAV-UNESP, where they were stored at $-20^{\circ} \mathrm{C}$ until processing.

Blood smear slides and thick blood smears were prepared using blood from finger puncture, performed using a lancet on each animal. The blood smears were fixed by means of methanol and were stained with Giemsa (inverted slide) diluted in buffered water for 35 minutes. The thick blood smears were pre-stained with buffered methylene blue for five seconds and then stained with Giemsa (Sigma-Aldrich, St. Louis, USA) for seven minutes, as recommended by WHO (2005).

\section{Serological test}

The indirect immunofluorescence assay (IFA) was performed using slides that had been prepared using antigens from culturing P. falciparum and human erythrocytes parasitized with $P$. malariae (from an infected human patient), in accordance with the technique described by Nardin et al. (1979). For the primate samples, anti-IgG from the rhesus monkey (Sigma-Aldrich, St. Louis, USA) was used as the conjugate, labeled with fluorescein isothiocyanate. For the human control serum, human anti-IgG was used (Sigma-Aldrich, St. Louis, USA), also labeled with fluorescein isothiocyanate, diluted as indicated by the manufacturer. The serum samples were diluted 1:20 in phosphate-buffered solution (PBS; $\mathrm{pH} 7.2$ ), and $10 \mu \mathrm{L}$ of this solution was used in each orifice of the slide, with the antigen substrate. Positive and negative control serum (infected and uninfected, respectively) from human patients was included in all the tests, donated by Dr. Silvia Di Santi, of the Superintendence for Endemic Disease Control of the State of São Paulo (SUCEN).

\section{Molecular tests}

DNA extraction from the total blood of NHP was performed using the QIAamp DNA Mini Kit (QIAGEN ${ }^{\circledR}$, Valencia, California, USA), in accordance with the manufacturer's recommendations.

PCR was performed using primers, as previously described (RUBIO et al., 1999; KIMURA et al., 1997; SNOUNOU et al., 1993), 
using water as the negative control and DNA of $P$. vivax and P. malariae, from infected patients, and DNA of $P$. falciparum, cultivated "in vitro", were used as positive controls. All of the DNA was donated by Dr. Silvia Di Santi (SUCEN).

The PCR products were subjected to $1.5 \%$ agarose gel electrophoresis, stained with ethidium bromide and viewed under UV light using the Chemidoc ${ }^{\mathrm{TM}}$ MP Image System (Bio Rad).

\section{Results}

\section{Blood smear and thick blood smear}

From June 2009 to April 2011, venous blood was randomly collected from neotropical primates, 50 individuals from CETAS-São Luis and 20 individuals captured from Sítio Aguahy Private Reserve (Figure 1).

A total of 140 slides from the 70 sampled animals were examined, of which 70 were blood smear slides and 70 were thick blood smears. Out of the total number of slides evaluated by means of examination under an optical microscope, five (7.1\%) slides from five different animals showed the presence of Plasmodium spp. (Figure 2). All the positive samples were from animals at CETAS: one from the species Callithrix jacchus and the remaining four from the species Sapajus apella.

\section{Serological test}

The 70 primate serum samples tested were not reactive to the IFA using antigens of $P$. falciparum, considering the initial dilution of 1:20 as the cutoff point. Only ten samples were tested using antigens of $P$. malariae (due to the low number of slides) and three were reactive for the dilution 1:20.

\section{Molecular tests}

Among the 70 samples tested in the three PCR protocols, amplified products for $P$. malariae were observed in 13 samples (Figure 3) using the protocol described by Rubio et al. (1999) and in nine samples (Figure 4) using the protocol described by Kimura et al. (1997).
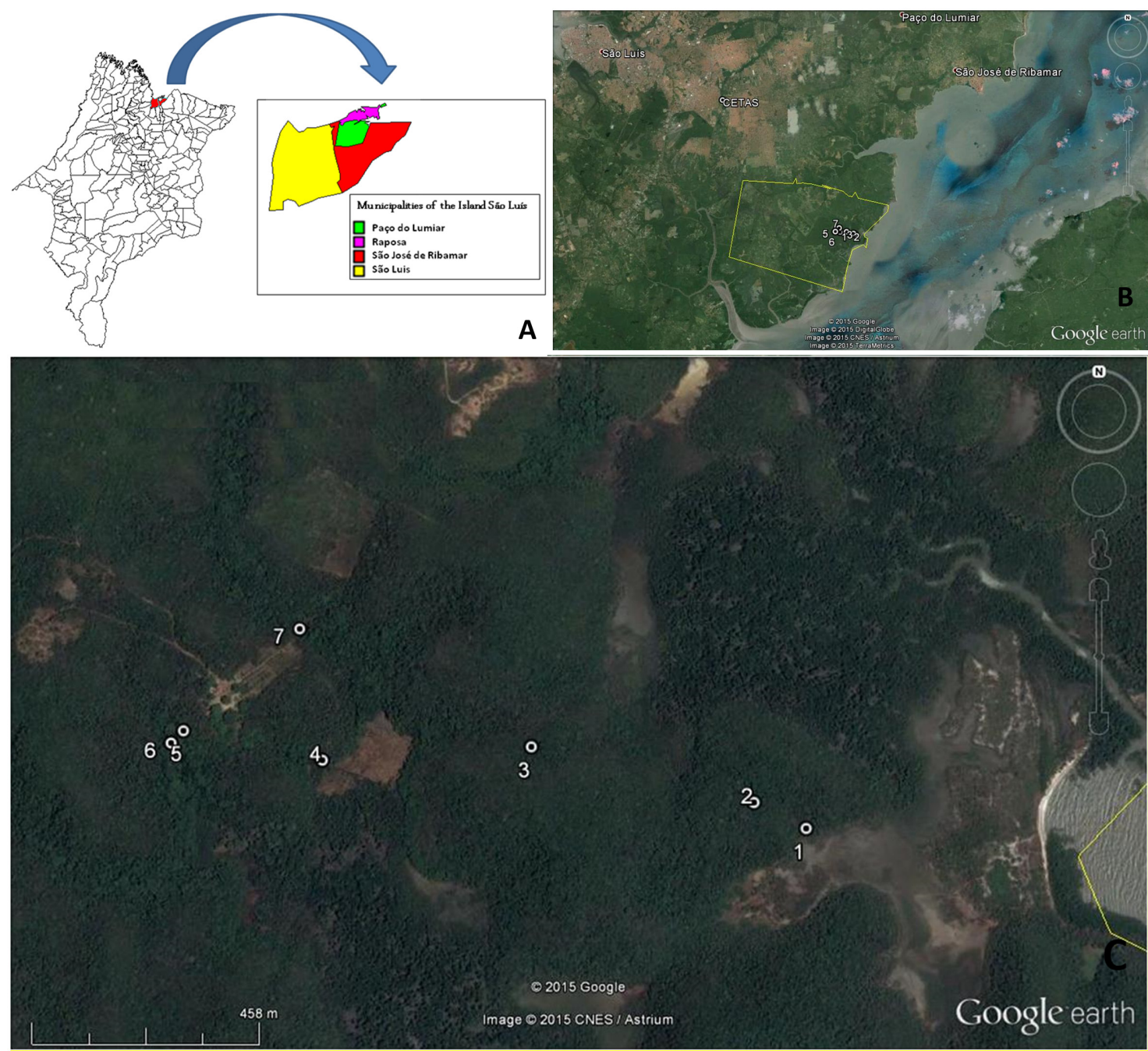

Figure 1. Captures sites: A - Map of Maranhão state showing the Island of São Luís (MapInfo Professional 7.5 SCP); B - points showing CETAS (São Luís) and Sítio Aguahy; C - distribuition of captures sites in Sítio Aguahy, São José de Ribamar. Source: Google Earth ${ }^{\circledR}$. 
Out of the 13 positive samples, eight (61.5\%) were from NHP from the Sítio Aguahy Private Reserve and five (38.5\%) from NHP at CETAS. All of them were NHP of the genus Sapajus (Table 1).

Interestingly, the five samples seen to be positive through optical microscopy did not amplify any product through PCR.

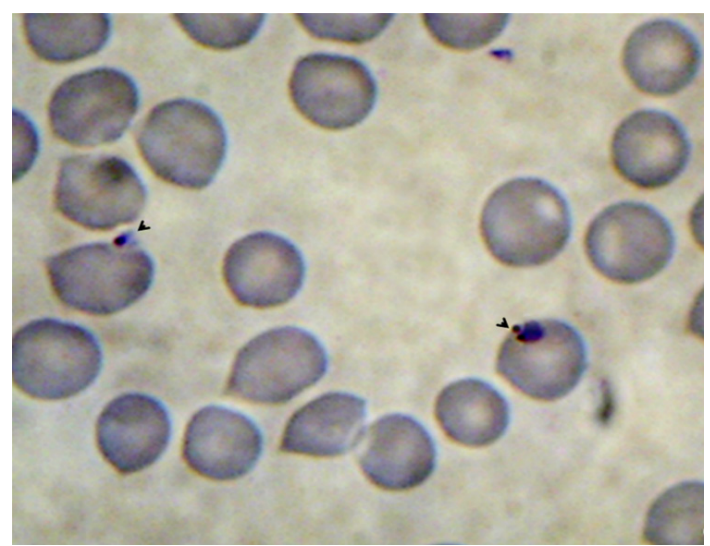

Figure 2. Plasmodium spp. in blood smear from Sapajus apella: arrows show ring-shaped trophozoites. Immersion objective lens.

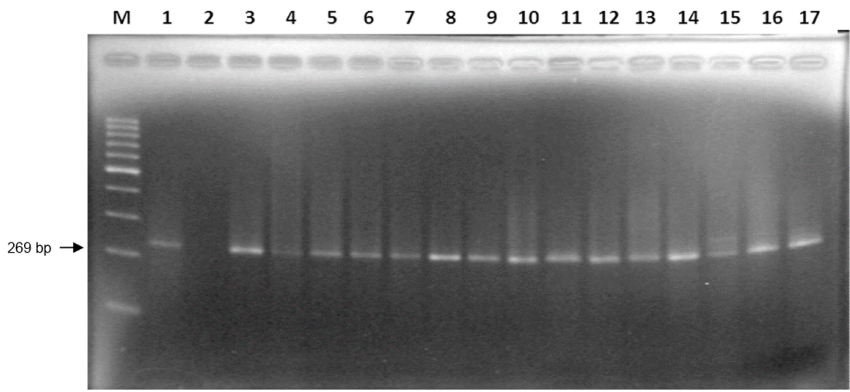

Figure 3. Photograph of electrophoresis on $1.5 \%$ agarose gel stained with ethidium bromide. The amplimers relate to semi-nested multiplex PCR (RUBIO et al., 1999) for the species $P$. malariae, $P$. vivax and P. falciparum. Column M: molecular tracer on scale of 100 base pairs (Invitrogen ${ }^{\circledR}$ ); column 1: positive control for P. malariae (269 bp); column 2: negative control; columns 3 to 10: positive samples of Sapajus sp. (Sítio Aguahy Private Reserve); columns 11 to 15: positive samples of Sapajus sp. (CETAS, São Luís).

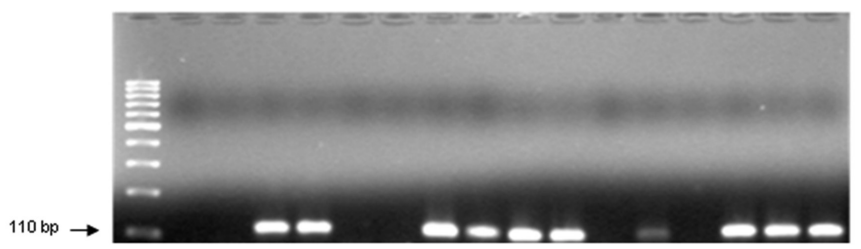

Figure 4. Photograph of electrophoresis on 1.5\% agarose gel stained with ethidium bromide. The amplimers showed in the picture relate to PCR on clones of the nine positive samples, using the protocol of Kimura et al. (1997) for Plasmodium malariae. Columns 3, 4, 7, 8, $9,10,12,14,15$ and 16 presented amplification of the clones 33.3, $34.3,35.2,36.2,37.3,38.3,39.3,40.1,40.2$ and 40.3, respectively. Column M: molecular tracer on scale of 100 base pairs (Invitrogen ${ }^{\circledR}$ ); columns 1, 2, 5, 6, 11 and 13: clones that were not amplified.
Table 1. Number of sampled neotropical primates in the years 2009-2011 according to the species, capture sites, gender and Plasmodium spp. results, São Luís, state of Maranhão, Brazil.

\begin{tabular}{cccc}
\hline Scientific name & Capture sites & Gender* & Total \\
\hline Aotus infulatus & CETAS & $1 \mathrm{~F}$ & 01 \\
Sapajus sp. & CETAS and & $30 \mathrm{M}(13)$ & 51 \\
& Sítio Aguahy & $/ 21 \mathrm{~F}(4)$ & \\
Callithrix jacchus & CETAS & $3 \mathrm{M}(1) / 2 \mathrm{~F}$ & 05 \\
Saimiri sciureus & CETAS and & $5 \mathrm{M} / 1 \mathrm{~F}$ & 06 \\
& Sítio Aguahy & & \\
Saguinus & CETAS & $2 \mathrm{M} / 5 \mathrm{~F}$ & 07 \\
midas niger & & & \\
Total & & $40 \mathrm{M}(14)$ & 70 \\
& & $130 \mathrm{~F}(4)$ & \\
\hline
\end{tabular}

*Numbers between brackets are Plasmodium spp. positive animals.

\section{Discussion}

The probable role of neotropical primates as reservoirs and their role in the epidemiological chain of human malaria have been discussed, but the natural transmission cycles from primate vectors to humans have not yet been fully established (ARRUDA et al., 1989; DUARTE et al., 2008; YAMASAKI et al., 2011).

Between the states composing the Legal Amazon, Maranhão is outstanding decreasing the number of cases of malaria, since the implementation of the Plan for Intensification of Malaria Control Actions. But the lack of consistence in continuing the basic actions of control and the migration within the state allowed some outbreaks to occur, as example the 1999-2000 outbreak, in the city of São Luís, and the 2000 outbreak in São Jose de Ribamar (GONÇALVES et al., 2009). This last one, in Guarapiranga village, near Sítio Aguahy, is the area where NHP were captured in this reasearch. As mentioned, this is an area of environmental preservation, which normally receives several people on the weekends for recreational activities such as fishing (SILVA et al., 2006). People that visit this area for fishing or going to the beach are closely to Sítio Aguahy Reserve, and sharing the same tracks from primates and other animals. This region is also rich in water collections. Inside the Guarapiranga village, there are two lakes, and Sítio Aguahy includes mangrove area, and an artificial pound, which serve as breeding grounds for many species of Anopheles. Also, the type of housing, open buildings without doors or windows, favor the free movement of the mosquito vector (SILVA et al., 2006).

In São Luís the recent years outbreaks have occurred on neighborhoods that are suffering rapid and unplanned growth, as we mention the outbreak occurred in 2000 in a the neighborhood called Residencial Paraíso, which has forest area and was devastated for building houses (RIBEIRO et al., 2005). It also has flooded areas, allowing the development of the mosquito vector. CETAS-São Luís receives animals from São Luís (captured in the backyard of homes) and from within the state, many do not have a history and come from seizure. But it is known that the majority of NHP received by CETAS had contact with humans for a time allowing the possibility of pathogen exchange.

Among the 70 NHP studied here, five animals were identified through optical microscopy (blood smear and thick blood 
smear slides) as presenting Plasmodium spp., thus representing $7.1 \%$ positivity. The parasitemia rate was always low: one to five parasites every two slides, per individual. Although the percentage positivity was low in the present study, it was still greater than in the majority of studies in the literature that used the same optical microscopy technique (CHINCHILLA et al., 2006; DUARTE et al., 2008; YAMASAKI et al., 2011). In Costa Rica, among 104 free-living howler monkeys (Alouatta palliata) that were studied, six primates $(5.7 \%)$ showed shapes identified as P. brasilianum (CHINCHILLA et al., 2006). In Brazil, in three different biomes (cerrado or savanna, Atlantic forest and semideciduous Atlantic forest), 448 NHP were sampled, among which $P$. brasilianum was also identified on seven plates (1.5\%) (DUARTE et al., 2008). Moreover, in the state of São Paulo, $P$. brasilianum was diagnosed on one blood sample slide out of a total of 50 from free-living howler monkeys (Alouatta guariba clamitans) (YAMASAKI et al., 2011). In addition, in French Guiana, among 214 free-living NHP that were investigated, $P$. brasilianum was detected through optical microscopy in ten samples (4.7\%), of which eight were from Alouatta seniculus and two from Saguinus midas (FANDEUR et al., 2000).

Optical microscopy did not allow identification of species within the genus Plasmodium because only one stage of development was found (trophozoites). The identification of species through microscopy is possible if mature blood forms are present, since trophozoites are very similar among the different species of Plasmodium. Additionally, this result was not surprising, because it is known that even through optical microscopy is the reference method and the method most applied in diagnosing Plasmodium in humans, its sensitivity and specificity are limited by various factors, including low parasite density (SNOUNOU et al., 1993). Since low parasitemia is common in natural infections in NHP, this technique does not present good sensitivity and it becomes necessary to observe all the fields of the slide. The low parasitemia of infection with $P$. malariae/brasilianum occurs due to the particular characteristics of the parasite, which only invades old red blood cells $(0.1 \%$ of the total) that are close to being removed from the circulation by the spleen. On the other hand, $P$. vivax and $P$. ovale preferentially invade young red blood cells and $P$. falciparum, red blood cells at any evolutionary stage.

Thus, we can infer that the animals in our study may have acquired the parasite and quickly eliminated the infection, thus making it difficult to observe the parasite in the blood and to detect antibodies. In this study, detection of the presence of anti-Plasmodium antibodies was not possible in any of the serum samples tested by means of IFA. It is important to highlight that antigens prepared from a culture of $P$. falciparum were used and that while cross-reactions with other species of Plasmodium are common, the reactivity for each species may be different. It is known that the erythrocytic stages of Plasmodium (merozoites, trophozoites, schizonts and gametocytes) present stage-specific antigens but that some antigenic proteins are shared by some Plasmodium species (DRUILHE et al., 1984), such as those that infect humans and primates in Brazil. Thus, we infer that, possibly due to the low quantity of antibodies present in samples, there would be a need to prepare antigens specific for each Plasmodium species.
Greater prevalence is obtained using the ELISA technique, both for human and primate serum samples, because this technique is more sensitive than IFA. In the present study, only the IFA technique was used. Volney et al. (2002) did not observe significant differences between these two techniques when they studied antibodies for malaria in humans and neotropical primates in French Guiana.

Information about the duration of anti-Plasmodium antibody circulation and the class and subclass of reactive antibodies (IgG1 and IgG2, among others), in studying the immune response of neotropical primates to these protozoa, still needs to be provided. Several authors (COHEN et al., 1974; DUARTE et al., 2007) have attributed importance to $\mathrm{IgE}$ with regard to infection by malaria, since this immunoglobulin appears at high levels during parasitic infections in humans and primates.

Significantly greater numbers of positive results were observed through the PCR technique, in comparison with optical microscopy. Out of the 70 samples analyzed, 13 (18.6\%) were positive in the reactions for the genus Plasmodium in the protocol proposed by Rubio et al. (1999) and, of these, nine samples were also positive for this genus using the protocol described by Kimura et al. (1997) However, the five samples $(7.1 \%)$, in which Plasmodium was identified through optical microscopy, were not positive according to PCR. Duarte et al. (2006, 2008) also identified divergences between the microscopy and PCR techniques in samples from NHP. The positive results obtained from the first technique were not confirmed from the second one. According to those authors, this may occur when new species of Plasmodium are circulating among Brazilian primates. Thus, the primers used were unable to amplify these samples.

Both in the protocol described by Kimura et al. (1997) and in the one described by Rubio et al. (1999), the species identified was $P$. malariae. The results from the present study do not diverge from the results already described in the literature, in which P. malariae is the most widely identified species in primates in Brazil. This highlights that this species is both molecularly and morphologically identical to $P$. brasilianum, the species that infects neotropical primates (LAL et al., 1988; FANDEUR et al., 2000; CARTER \& MENDIS, 2002; LECLERC et al., 2004). These results corroborate the results found in French Guiana, which identified $P$. brasilianum in 17 NHP ( $=154$ ), through the nested PCR, (FANDEUR et al., 2000). Moreover, in Brazil, in a study on neotropical primates in two different biomes, the Atlantic forest $(n=71$, positivity $=12.6 \%)$ and the semi-deciduous Atlantic forest $(n=235$, positivity $=6.7 \%$ ), the greatest positivity was for $P$. malariae/P. brasilianum: $5.6 \%$ and $5.5 \%$, respectively (DUARTE et al., 2006).

Recent data obtained by Bueno et al. (2013) with Amazonian primates, assure that $P$. malariae is the most commonly species found in the animals belonging to this area. These authors looked for Plasmodium in twelve different species of NHP, from two Amazonian states (Rondônia and Amazonas), performing 19 animals samples. Using morphological characterization and PCR, four (21\%) animals were positive. Also, the authors give an important recommendation to control the spread of malaria: 
test samples of Amazonian primates for Plasmodium before any animal circulation.

It is also important to take into consideration that in extremely sensitive PCR techniques, the 'all or nothing' phenomenon can occur, in other words, detection of possible false positive or false negative results. This occurs when trying to detect Plasmodium spp. in samples with very low parasitemia, in which the amount of DNA added to the PCR is close to the detection limit. In these cases, it is likely that the same sample is positive a few times and negative in other reactions (BOONMA et al., 2007). This occurred during the present study, using the PCR protocol proposed by Rubio et al. (1999), in which the samples MP28, MP30 and MP37 were amplified in the first genus reaction, but when this was repeated, there was no amplification, even using the same DNA template. In a third reaction, the samples MP28, MP30 and MP37 were amplified in the same way as in the first reaction performed.

The natural behavior of neotropical primates, in which they travel long distances, can affect the dissemination of Plasmodium in rural or forest environments. Primates are naturally infection of Plasmodium, and ecological imbalance may have an impact on the public health of indigenous and rural populations, as well as representing an even more serious complication in relation to development of vaccines.

\section{Acknowledgements}

To the staff of the Wild Animal Screening Center/IBAMA, in São Luís, Maranhão, mainly Roberto Veloso, and to the staff of Sítio Aguahy (João and Maria). Also to the Research Support Foundation of the State of São Paulo, which funded the scholarship (FAPESP, Procedural No. 10/01598-9) and the project (Regular Support, Procedural No. 10/12820-4).

\section{References}

Arruda M, Nardin EH, Nussenzweig RSS, Cochrane AH. Sero-epidemiological studies of malaria in Indian tribes and monkeys of the Amazon Basin of Brazil. Am J Trop Med Hyg 1989; 41(4): 379-385. PMid:2508499.

Boonma P, Christensen PR, Suwanarusk R, Price RN, Russell B, LekUthai U. Comparison of three molecular methods for the detection and speciation of Plasmodium vivax and Plasmodium falciparum. Malar J 2007; 6(1): 124-130. http://dx.doi.org/10.1186/1475-2875-6-124. PMid:17868467.

Bueno MG, Rohe F, Kirchgatter K, Di Santi SMF, Guimarães LO, Witte $\mathrm{CL}$, et al. Survey of Plasmodium spp. in free-ranging neotropical primates from the Brazilian Amazon region impacted by anthropogenic actions. EcoHealth 2013; 10(1): 48-53. http://dx.doi.org/10.1007/s10393-0120809-z. PMid:23404035.

Carter R, Mendis KN. Evolutionary and historical aspects of the burden of malaria. Clin Microbiol Rev 2002; 15(4): 564-594. http://dx.doi. org/10.1128/CMR.15.4.564-594.2002. PMid:12364370.

Chinchilla M, Guerrero OM, Gutiérrez G, Sánchez R. Presencia de Plasmodium brasilianum (Apicomplexa, Plasmodidae) en el mono congo (Alouatta palliata, Primates: Cebidae) de Costa Rica. Importancia epidemiológica en relación con el ser humano. Parasitol Latinoam 2006; 61(3-4): 192-196. http://dx.doi.org/10.4067/S0717-77122006000200018.

Coatney GR, Collins WE, Contacos PG. The primates malarias. Mariland; 1971.

Cohen S, Butcher GA, Mitchell GH. Mechanisms of immunity to malaria. Bull World Health Organ 1974; 50(3-4): 251-257. PMid:4548392.

Deane LM. Simian malaria in Brazil. Mem Inst Oswaldo Cruz 1992;87(S3 Suppl Suppl 3): 1-20. http://dx.doi.org/10.1590/S0074-02761992000700001. PMid:1343676.

Druilhe P, Puebla RM, Miltgen F, Perrin L, Gentilini M. Species- and stage-specific antigens in exoerythrocytic stages of Plasmodium falciparum. Am J Trop Med Hyg 1984; 33(3): 336-341. PMid:6203418.

Duarte AM, Malafronte RS, Cerutti C Jr, Curado I, de Paiva BR, Maeda AY, et al. Natural Plasmodium infections in Brazilian wild monkeys: reservoirs for human infections? Acta Trop 2008; 107(2): 179-185. http://dx.doi.org/10.1016/j.actatropica.2008.05.020. PMid:18620330.

Duarte AMRDC, Porto MAL, Curado I, Malafronte RS, Hoffmann EHE, Oliveira SG, et al. Widespread occurrence of antibodies against circumsporozoite protein and against blood forms of Plasmodium vivax, P. falciparum and P. malariae in Brazilian wild monkeys. J Med Primatol 2006; 35(2): 87-96. http://dx.doi.org/10.1111/j.1600-0684.2006.00148.x. PMid:16556295.

Duarte J, Deshpande P, Guiyedi V, Mécheri S, Fesel C, Cazenave PA, et al. Total and functional parasite specific IgE responses in Plasmodium falciparum-infected patients exhibiting different clinical status. Malar J2007; 6(1): 1-13. http://dx.doi.org/10.1186/1475-2875-6-1. PMid:17204149.

Escalante AA, Barrio E, Ayala FJ. Evolutionary origin of human and primate malarias: evidence from the circumsporozoite protein gene. $\mathrm{Mol}$ Biol Evol 1995; 12(4): 616-626. PMid:7659017.

Escalante AA, Freeland DE, Collins WE, Lal AA. The evolution of primate malaria parasites based on the gene encoding cytochrome $b$ from the linear mitochondrial genome. Proc Natl Acad Sci USA 1998; 95(14): 8124-8129. http://dx.doi.org/10.1073/pnas.95.14.8124. PMid:9653151.

Eyles DE. The species of simian malaria: taxonomy, morphology, life cycle, and geographical distribution of the monkey species. J Parasitol 1963; 49(6): 866-887. http://dx.doi.org/10.2307/3275712. PMid:14084190.

Fandeur T, Volney B, Peneau C, de Thoisy B. Monkeys of the rainforest in French Guiana are natural reservoirs for P. brasilianum/P. malariae malaria. Parasitology 2000; 120(Pt 1): 11-21. http://dx.doi.org/10.1017/ S0031182099005168. PMid:10726261.

Gonçalves EG, Machado RLD, Santos AR, Raposo CCBS, Matos WB, Silva AR. Caracterização de genótipos de Plasmodium vivax na Ilha de São Luís, Estado do Maranhão. Rev Soc Bras Med Trop 2009; 42(3): 315-317. http://dx.doi.org/10.1590/S0037-86822009000300014. PMid:19684981.

Guerrant RL, Blackwood BL. Threats to global health and survival: the growing crises of tropical infectious diseases--our "unfinished agenda". Clin Infect Dis 1999; 28(5): 966-986. http://dx.doi.org/10.1086/514765. PMid:10452620.

Kimura M, Kaneko O, Liu Q, Zhou M, Kawamoto F, Wataya Y, et al. Identification of the four species of human malaria parasites by nested PCR that targets variant sequences in the small subunit rRNA gene. Parasitol Int 1997; 46(2): 91-95. http://dx.doi.org/10.1016/S13835769(97)00013-5.

Lal AA, Cruz VF, Collins WE, Campbell GH, Procell PM, McCutchan TF. Circumsporozoite protein gene from Plasmodium brasilianum. Animal 
reservoirs for human malaria parasites? J Biol Chem 1988; 263(12): 5495-5498. PMid:3128542.

Leclerc MC, Hugot JP, Durand P, Renaud F. Evolutionary relationships between 15 Plasmodium species from new and old world primates (including humans): an 18S rDNA cladistic analysis. Parasitology 2004; 129(Pt 6): 677-684. http://dx.doi.org/10.1017/S0031182004006146. PMid:15648690.

Nardin EH, Nussenzweig RS, McGregor IA, Bryan JH. Antibodies to sporozoites: their frequent occurrence in individuals living in an area of hyperendemic malaria. Science 1979; 206(4418): 597-599. http://dx.doi. org/10.1126/science.386511. PMid:386511.

Oliveira-Pereira YN, Rebêlo JMM. Espécies de Anopheles no município de Pinheiro (Maranhão), área endêmica de malária. Rev Soc Bras Med Trop 2000; 33(5): 443-450. http://dx.doi.org/10.1590/S003786822000000500006. PMid:11064581.

Perelman P, Johnson WE, Roos C, Seuánez HN, Horvath JE, Moreira MAM, et al. A molecular phylogeny of living primates. PLoS Genet 2011; 7(3): e1001342. http://dx.doi.org/10.1371/journal.pgen.1001342. PMid:21436896.

Ribeiro MCT, Gonçalves EG, Tauil PL, Silva AR. Aspectos epidemiológicos de um foco de malária no município de São Luis, MA. Rev Soc Bras Med Trop 2005; 38(3): 272-274. http://dx.doi.org/10.1590/S003786822005000300016 . PMid:15895185.

Rubio JM, Benito A, Berzosa PJ, Roche J, Puente S, Subirats M, et al. Usefulness of seminested multiplex PCR in surveillance of imported malaria in Spain. J Clin Microbiol 1999; 37(10): 3260-3264. PMid:10488189.
Silva AR, Tauil PL, Bastos JL Jr, Matos WB, Costa EAP, Gonçalves EG. Aspectos da transmissão focal de malária na Ilha de São Luis, Maranhão. Rev Soc Bras Med Trop 2006; 39(3): 250-254. http://dx.doi.org/10.1590/ S0037-86822006000300004. PMid:16906247.

Snounou G, Viriyakosol S, Zhu XP, Jarra W, Pinheiro L, Rosario VE, et al. High sensitivity of detection of human malaria parasites by the use of nested polymerase chain reaction. Mol Biochem Parasitol 1993; 61(2): 315-320. http://dx.doi.org/10.1016/0166-6851(93)90077-B. PMid:8264734.

Volney B, Pouliquen JF, De Thoisy B, Fandeur T. A sero-epidemiological study of malaria in human and monkey populations in French Guiana. Acta Trop 2002; 82(1): 11-23. http://dx.doi.org/10.1016/S0001706X(02)00036-0. PMid:11904099.

Warrel DA. Clinical features of malaria. In: Warrell DA, Gilles HM, editors. Essential malariology. 4th ed. Oxford: University Press; 2002. p. 191-205. International Students Edition.

World Health Organization - WHO. World Malaria Report 2005 [online]. Geneva; 2005. [cited 2014 Set 2]. Available from: http://whqlibdoc.who. int/publications/2005/9241593199_eng.pdf

Yamasaki T, Duarte AMRC, Curado I, Summa MEL, Neves DVDA, Wunderlich G, et al. Detection of etiological agents of malaria in howler monkeys from Atlantic Forests, rescued in regions of São Paulo city, Brazil. JMed Primatol 2011; 40(6): 392-400. http://dx.doi.org/10.1111/j.16000684.2011.00498.x. PMid:21933192. 